\title{
READING OTHER-WISE: Re-envisaging the reading practices and place of the socially engaged biblical scholar ${ }^{1}$
}

Gerald West

University of Natal

\begin{abstract}
This article attempts to chart the reading strategies and resources of ordinary African 'readers' of the Bible and to probe the place of the socially engaged biblical scholar in relation to these strategies and resources. The first part of the article offers a historical and methodological account of the early encounters of Africans with the Bible. Vincent Wimbush's interpretative history of the Bible among African Americans serves a useful heuristic function here. The second part of the article explores how ordinary African 'readers' actually 'read' the Bible - a process which I refer to as 're-membering' the Bible. The third part of the article draws on a range of theoretical perspectives, including postmodern, postcolonial, and womanist/feminist notions of subjectivity and identity in order to re-envisage the reading practices and place of the socially engaged biblical scholar.
\end{abstract}

\section{Introduction}

I begin by numbering and naming 'the other' who is the subject of my discourse in this article. Ordinary African 'readers' of the Bible from poor and marginalized communities in South Africa constitute 'the other' of my article. There is something of the slogan in this formulation, and I acknowledge its imprecision. But slogans have their place, even in academic reflection, and the indeterminate designation reminds us of the shifting boundaries that constitute this 'other'. The slowly changing socio-economic profile of the South African population and the constellations of forces and factors that currently shape our subjectivities reconstitute who this 'other' is from day to day. However, if the primary interlocutor of liberation (and life) hermeneutics is the poor and marginalized (Frostin 1988) and if Jesus was prophetic in stating that the poor will always be with us (John 12:8), then this article still has a contribution to offer.

The bulk of the article attempts to delineate with more precision the reading strategies and resources of ordinary African 'readers' of the Bible and to probe the place of the socially engaged biblical scholar in relation to these strategies and resources. This part of the article draws on a range of theoretical perspectives, including postmodern, postcolonial, and womanist/feminist notions of subjectivity and identity.

\section{Will 'the other' please stand up!}

I do not want to qualify my comments concerning 'the ordinary African 'reader' of the Bible from poor and marginalized communities' much further, except to make it quite clear that my reflections arise from work in very specific and actual communities. Each of these

1. This article is based on a paper presented to the Workshop on Contextual Hermeneutics, Stellenbosch, June 1997. I have developed aspects of this article in another article which concentrates on postcolonial dimensions of the discussion (see West 1997). 
communities could be surveyed and categorized sociologically, and in much of my work I have attempted to provide a profile of who I am reading with in a particular case (see, for example, West 1995a and West 1993). My purpose in this article, however, is to reflect more generally across these communities on the reading resources and strategies I and others have encountered there.

One more observation is appropriate concerning these 'others'; they are the most 'other', in David Tracy's sense (Tracy 1987:72, 90, 100-104, 141, n.56), and they are numerically the most - they are the majority of 'readers' of the Bible in South Africa.

\section{Other reading strategies and resources}

Before I come to a more empirical exploration of the reading strategies and resources of 'the others' it may be instructive to approach the subject from an historical perspective. In order to do this I will draw, heuristically, on Vincent Wimbush's interpretative history of the Bible among African Americans. I realize that there are many significant differences between African American transactions with the Bible and indigenous South African transactions with the Bible; however, the similarities are striking and so, in the absence of a detailed interpretative history of the Bible among indigenous South Africans, Wimbush's outline has heuristic value.

African slaves' initial encounter with the Bible is characterized, according to Wimbush, by a combination of rejection, suspicion, and awe of 'Book Religion'. ${ }^{2}$ During this period the story of European colonization and conquest of 'the New World' is remarkably similar to that of their colonization and conquest of South Africa.

They conquered native peoples and declared that European customs, languages, and traditions were the law. The Europeans' embrace of the Bible helped to lend this process legitimacy. Since many of them through their reading of and reference to the Bible had already defined themselves as dissenters from the dominant social, political, and religious traditions in their native countries, they found it a rather natural resource in the context of the New World. The Bible functioned as a cultural image reflector, as a road map to nation-building. It provided the Europeans justification to think of themselves as a 'biblical nation,' as God's people called to conquer and convert the New World to God's way as they interpreted it (Wimbush 1991:84).

While the Bible did play a role in the missionizing of African slaves, its role was not primary and so its impact was indirect. 'It was often imbedded within catechetical materials or within elaborate doctrinal statements and formal preaching styles' (Wimbush 1993:130). When African slaves did encounter the Bible is was from the perspective of cultures steeped in oral tradition. From this perspective the concept of religion and religious power circumscribed by a book was 'at first frightful and absurd, thereafter, ... awesome and fascinating' (Wimbush 1993:131). As illiterate peoples with rich, well-established, and elaborate oral traditions the majority of the first African slaves were suspicious of and usually rejected 'Book Religion'. However, as Wimbush notes, '[i]t did not take them long to associate the Book of 'Book religion' with power' (Wimbush 1991:85). So early in their encounter with 'the Book', before they began to appropriate the Bible in an empowering and affirmative manner, their 'capacity and willingness to engage 'the Book' were significant, for they demonstrated the ability of African slaves to adapt themselves to different understandings of reality', and so to survive (Wimbush 1991:85).

2. For a similar, albeit brief, account of the Bible's arrival in Africa see Getui 1997:94. 
During what Wimbush classifies as the second period of encounter with the Bible, African slaves began to appropriate and own the Bible. With the growth of the non-establishment, evangelical, camp meeting revivalist movements Africans 'began to encounter the Bible on a large and popular scale' (Wimbush 1993:131). As significant numbers of Africans converted to Christianity, even establishing their own churches and denominational groups, they began to embrace the Bible.

What did not go unnoticed among the Africans was the fact that the white world they experienced tended to explain its power and authority by appeal to the Bible. So they embraced the Bible, transforming it from the book of the religion of whites - whether aristocratic slavers or lower class exhorters - into a source of (psychic-spiritual) power, a source of inspiration for learning and affirmation, and into a language world of strong hopes and veiled but stinging critique of slave-holding Christian culture (Wimbush 1993:131).

The point Wimbush is making here is that African slaves, like their conquered and colonized cousins in Africa, learned, appropriated, adapted, and added to the hermeneutic moves of the European 'masters'. African slaves would have noted the diversity of readings the Bible could inspire, including cultural, political, and denominational (religious) readings. They would also have observed the selective way in which the missionaries and preachers read the Bible; they read certain parts and ignored others (Wimbush 1991:86). The various forms in which readings of the Bible could be articulated were appropriated and amplified: 'in song, prayers, sermons, testimonies, and addresses' (Wimbush 1991:86). If the missionaries and masters could interpret the 'the Book' under the guidance of the Spirit, then so could they.

And interpret they did. They were attracted primarily to the narratives of the Hebrew Bible dealing with the adventures of the Hebrews in bondage and escaping from bondage, to the oracles of the eighth-century prophets and their denunciations of social injustice and visions of social justice, and to the New Testament texts concerning the compassion, passion, and resurrection of Jesus. With these and other texts, the African American Christians laid the foundations for what can be seen as an emerging 'canon'. In their spirituals and in their sermons and testimonies African Americans interpreted the Bible in the light of their experiences. Faith became identification with the heroes and heroines of the Hebrew Bible and with the long-suffering but ultimately victorious Jesus. As the people of God in the Hebrew Bible were once delivered from enslavement, so, the Africans sang and shouted, would they be delivered. As Jesus suffered unjustly but was raised from the dead to new life, so, they sang, would they be 'raised' from their 'social death' to new life. So went the songs, sermons, and testimonies (Wimbush 1991:86-87).

These various forms - spirituals, sermons, and testimonies - reflect the hermeneutical processes whereby African slaves appropriated the Bible as their own property. They 'reflect a hermeneutic characterized by a looseness, even playfulness, vis-à-vis the biblical texts themselves' (Wimbush 1991:88). Wimbush goes on to offer a fuller description of this 'looseness' and 'playfulness' (Wimbush 1991:88-89). A looseness and playfulness towards the text includes the following strategies: interpretation 'was not controlled by the literal words of the texts, but by social experience'; texts were heard and retold more than read; texts 'were engaged as stories that seized and freed the imagination'; biblical texts were usually interpreted collectively; biblical stories 'functioned sometimes as allegory, as parable, or as veiled social criticism' in a situation where survival demanded disguised forms of resisting discourse (Wimbush 1991:88; see also below); certain texts in the canon were read and others ignored. 
In addition to offering a preliminary description of these formative hermeneutical processes, Wimbush also wants to argue that the array of interpretative strategies forged in this period of African American encounter with the Bible are foundational: all other readings would in some sense be built upon and judged by them. The beginning of the African American encounter with the Bible has functioned, according to Wimbush, 'as phenomenological, socio-political and cultural foundation' for subsequent periods (Wimbush 1993:131). The Bible, understood as 'the white folk's book', 'was accepted but not interpreted in the way that white Christians and the dominant culture in general interpreted it' (Wimbush 1991:89).

In the absence of a careful analysis and history of the early encounters of indigenous South Africans with the Bible, the first two phases of Wimbush's interpretative history are suggestive, especially in two respects. His characterization of the hermeneutics of encounter as ' $a$ looseness, even playfulness' towards the biblical text and his claim that such a hermeneutics is foundational for later phases in the ongoing encounter with the Bible are particularly insightful and significant, and resonate with my own research and reflections on the South African context. And we can even find echoes in the work of some South African Black theologians

The encounter between indigenous South Africans and the Bible is usually recounted by South African Black theologians in broad strokes: 'When the white man came to our country he had the Bible and we had the land. The white man said to us 'let us pray'. After the prayer, the white man had the land and we had the Bible' (Mofokeng 1988:34). With this as their starting point, Black theologians like Itumeleng Mosala and Takatso Mofokeng go on to focus on the kinds of scholarly strategies and reading resources that are most appropriate for reading the Bible in the South African context of the 1980s. But a careful reading of their work does provide glimpses of 'other' reading resources and interpretative strategies.

Drawing from and elaborating on the work of Mosala, Mofokeng argues that the Bible is both a problem and a solution. ${ }^{3}$ The 'external' problem of the Bible is the oppressive and reactionary use of the Bible by white Christians. The internal problem is the Bible itself (Mofokeng 1988:37). Like Mosala, he is critical of those who concentrate on only the external problem, those who 'accuse oppressor-preachers of misusing the Bible for their oppressive purposes and objectives' (Mofokeng 1988:37), or who accuse 'preachers and racist whites of not practising what they preach' (Mofokeng 1988:38). It is clear, Mofokeng argues, that these responses are 'based on the assumption that the Bible is essentially a book of liberation' (Mofokeng 1988:37). While Mofokeng concedes that these responses have a certain amount of truth to them, the crucial point he wants to make is that there are numerous 'texts, stories and traditions in the Bible which lend themselves to only oppressive interpretations and oppressive uses because of their inherent oppressive nature'. What is more, any attempt 'to 'save' or 'coopt' these oppressive texts for the oppressed only serve the interests of the oppressors' (Mofokeng 1988:38).

Young blacks in particular, Mofokeng goes on to argue, 'have categorically identified the Bible as an oppressive document by its very nature and to its very core' and suggest that the best option 'is to disavow the Christian faith and consequently be rid of the obnoxious Bible'. Indeed, some 'have zealously campaigned for its expulsion from the oppressed Black community', but, he notes, with little success. The reason for this lack of success, Mofokeng suggests, is

largely due to the fact that no easily accessible ideological silo or storeroom is being offered to the social classes of our people that are desperately in need of liberation. African

3. Mofokeng's article clearly draws extensively on Mosala's work although there is no explicit reference to it. 
traditional religions are too far behind most blacks while Marxism, is to my mind, far ahead of many blacks, especially adult people. In the absence of a better storeroom of ideological and spiritual food, the Christian religion and the Bible will continue for an undeterminable period of time to be the haven of the Black masses par excellence.

Given this situation of very limited ideological options, Mofokeng continues, 'Black theologians who are cornmitted to the struggle for liberation and are organically connected to the struggling Christian people, have chosen to honestly do their best to shape the Bible into a formidable weapon in the hands of the oppressed instead of leaving it to confuse, frustrate or even destroy our people' (Mofokeng 1988:40).

But it was not only Black theologians who were shaping the Bible into a formidable weapon. Mofokeng himself offers us a glimpse of the 'shaping' work of others as he characterizes the 'reading' strategies and resources of ordinary black Christians. Encountering the Bible

As members of a people whose story of pain, fears and hopes has been suppressed, they are enabled, by their physical and psychological scars, together with the analytical tools they have chosen, to discover the suppressed and forgotten stories of the weak and the poor of the Bible. These seem, according to them, to be the stories wherein God is identifying with the forgotten and the weak and is actively retrieving them from the margins of the social world. It is through these stories that God the creator of humans is manifested as the God of the oppressed and accepted as such. This creator God acts incarnately in Jesus to end the rampant enmity in creation and restore real humanity to people. Only the reading of these stories of the downtrodden God among the downtrodden of this world strengthens the tormented faith of the oppressed of our time, as well as enhancing the quality of their cornmitment to the physical struggle for liberation. This discovery constitutes the liberation of the Bible from the clutches of the dominant in the Christian fold who impose the stories that justify their victories onto the oppressed (Mofokeng 1988:41).

This paragraph of Mofokeng's resonates with the work of Wimbush cited earlier, but Mofokeng is less precise in his description and analysis of 'the analytical tools they [ordinary black South Africans] have chosen'. But he, like Mosala, is clear that black experience, or the experience of 'blackness' (Frostin 1988:86-87), is the starting point. Significantly, Mofokeng seems willing to acknowledge and even to allow for whatever analytical tools ordinary African Christians choose for the interpretative task, although there are indications that he wants to insist that certain tools are more appropriate than others. Mosala definitely wants to insist on this point; in fact, the central thrust of all his work is to argue that the only appropriate analytical and interpretative tools are historical-materialist ones. But while Mosala does seem to insist that these are the only appropriate interpretative and analytical procedures to be used in the encounter with the Bible, there are moments when even he alludes to other resources in the black community. He argues, for example, that the uncritical 'Word of God' approach of many Black theologians to the Bible has been 'surpassed by the largely illiterate black working class and poor peasantry who have defied the canon of Scripture, with its ruling class ideological basis, by appropriating the Bible in their own way using the cultural tools emerging out of their struggle for survival' (Mosala 1986:184). ${ }^{4}$ Such statements, and similar statements by Mofokeng cited above, require more careful scrutiny. However, because neither Mosala nor Mofokeng elaborate on these statements, we will have to look elsewhere.

What are the tools that ordinary African interpreters of the Bible use to appropriate the

4. Unfortunately, Mosala does not elaborate on this. 
Bible? How do they 'read'? In describing four cases of ordinary indigenous 'readers' reading the Bible (West 1995:174-200), I have demonstrated that while there may appear to be some affinities between the reading strategies and resources of ordinary 'readers' and the modes of reading of socially engaged biblical scholars, ${ }^{5}$ the situation is more complex. There are certainly interesting similarities, but we must recognise that something fundamentally different is going on in the reading processes of ordinary indigenous 'readers'. As I have indicated, Wimbush suggests that such a hermeneutic is 'characterized by a looseness, even playfulness, vis-à-vis the biblical texts themselves'. Mosala's concern is that such ways of appropriating the Bible

cannot be allowed to substitute for a theoretically well-grounded biblical hermeneutics of liberation. The reason for this is that, while texts that are against oppressed people may be co-opted by the interlocutors of the liberation struggle, the fact that these texts have their ideological roots in oppressive practices means that the texts are capable of undergirding the interests of the oppressors even when used by the oppressed. In other words, oppressive texts cannot be totally tamed or subverted into liberating texts (Mosala 1989:30). ${ }^{6}$

Mosala is worried about two things here. First, he is worried that black biblical hermeneutics might suffer from an 'unstructural understanding of the Bible' and, second, that both as a consequence and as a reason, it might also suffer from an 'unstructural understanding' of the black experience and struggle (Mosala 1989:32). ${ }^{7}$ Central to Mosala's hermeneutics of liberation is the search for a theoretical perspective that can locate both the Bible and the black experience within appropriate historical contexts (Mosala 1989:24). As already mentioned, for Mosala a historical-materialist understanding of struggle provides the tools for reading both black history and culture and the Bible.

Mosala's concerns are clear, but are they the whole story? What if ordinary indigenous Africans have both a more 'structural' understanding of the Bible and their social context than we recognize? What if they have disguised their actual 'structural' understanding in order to survive? And what if they have achieved this 'structural' understanding using resources of their own? Surely the presence of such already existing resources would be significant, especially if as we are to use local resources, as for example Tinyiko Maluleke urges us to, in the process of reconstructing our country? (Maluleke 1996:17) - particularly if these resources can be traced back in some form to the reading resources of our African ancestors in their transactions with the Bible.

When it comes to understanding the alleged silence or 'unstructural' understanding of the poor and marginalised we find thick and thin accounts of ideological hegemony. The thick version emphasizes the role of ideological state apparatuses, such as education systems, the church, and government structures, in controlling the symbolic means of production, just as factory owners monopolize the material means of production. 'Their ideological work secures the active consent of subordinate groups to the social arrangements that reproduce their subordination' (Scott 1990:73). The thin theory of hegemony makes less grand claims for the ideological control of the ruling class. What ideological domination does accomplish, according to this version,

5. My focus has always been on the work of socially engaged biblical scholars (engaged, for example, in liberation hermeneutics) rather than those biblical scholars who choose to hide their social commitments and interests.

6. Nothing, Mosala later adds, 'could be more subversive to the struggle for liberation than enlisting the oppressors and exploiters as comrades in arms' (33).

7. The phrase 'unstructural understanding' is taken from the work of Norman K Gottwald. 
is to define for subordinate groups what is realistic and what is not realistic and to drive certain aspirations and grievances into the realm of the impossible, of idle dreams. By persuading underclasses that their position, their life-chances, their tribulations are unalterable and inevitable, such a limited hegemony can produce the behavioral results of consent without necessarily changing people's values. Convinced that nothing can possibly be done to improve their situation and that it will always remain so, it is even conceivable that idle criticisms and hopeless aspirations would be eventually extinguished (Scott 1991:74).

But, the argument continues, because 'the logic of domination represents a combination of historical and contemporary ideological and material practices that are never completely successful, always embody contradictions, and are constantly being fought over within asymmetrical relations of power' (Giroux 1985:xii), 'organic intellectuals', who can learn with the poor and marginalized while simultaneously helping them to foster modes of self-education and struggle against various forms of oppression, are able to point to the spaces, contradictions, and forms of resistance that raise the possibility for social struggle. However, and this is a key element of this position, oppressed people's accommodation to the logic of domination may mean that they actively resist emancipatory forms of knowledge offered by organic intellectuals (Giroux 1985:xviii-xxiii).

Such accounts of ideological hegemony argue that 'when oppressed people live in silence, they use the words of their oppressors to describe their experience of oppression. Only within the praxis of liberation and in dialogue with what Antonio Gramsci called 'organic intellectuals' is it possible for the poor to break this silence and create their own language' (Frostin 1988:10). So within liberation theologies, whether they be Latin American, black, womanist, or feminist, the role of the intellectual is crucial in breaking 'the culture of silence' - in enabling a language (or, in Mosala's terms, in enabling a 'structural' analysis).

But what if this traditional Marxist analysis of domination and resistance is inadequate and the poor and marginalized have not accommodated themselves to the logic of domination? What if they already have a language? James Scott's work on 'domination and the arts of resistance' opens up such possibilities. Scott problematises both thick and thin versions of ideological hegemony, and so too the role of the intellectual. In his detailed study of domination and resistance we find a more nuanced analysis, arguing that theories of hegemony and false consciousness do not take account of what he calls 'the hidden transcript' 8

According to Scott, subordinate groups create out of their ordeal of domination 'a 'hidden transcript ' that represents a critique of power spoken behind the back of the dominant' (Scott 1990:xii). The crucial point of Scott's detailed argument is that '[t]he public transcript, where it is not positively misleading, is unlikely to tell the whole story about power relations. It is frequently in the interest of both parties to tacitly conspire in misrepresentation' (Scott 1990:2). So social analysis which focuses on the public transcript, as most social analysis does, is focusing on the formal relations between the powerful and weak (Scott 1990:13), but is not attempting to 'read, interpret, and understand the often fugitive political conduct of subordinate groups' (Scott 1990:xii; see also Comaroff 1985:261). A focus on the hidden transcript, where it is accessible in the rumours, gossip, folktales, songs, gestures, jokes, and theatre of the poor and marginalized, or the more public infrapolitics of popular culture (Scott 1990:198), reveals forms of resistance and defiance. Such analysis argues that 'Unless one can penetrate the official transcript of both subordinates and elites, a reading of the social evidence will almost

8. For a similar analysis from a womanist perspective see Patricia Hill Collins 1990:10-12, 40 note 3, 93-98, 139-154. 
always represent a confirmation of the status quo in hegemonic terms'(Scott 1990:90).

But is there still not a case for Gramsci's notion of the dominated consciousness of subordinate groups? For Gramsci hegemony works primarily at the level of thought as distinct from the level of action (Gramsci 1971: 333). Scott turns this around. He considers 'subordinate classes less constrained at the level of thought and ideology, since they can in secluded settings speak with comparative safety, and more constrained at the level of political action and struggle, where the daily exercise of power sharply limits the options available to them' (Scott 1990:91). So, he argues,

subordinate groups have typically learned, in situations short of those rare all-or-nothing struggles, to clothe their resistance and defiance in ritualisms of subordination that serve both to disguise their purposes and to provide them with a ready route of retreat that may soften the consequences of a possible failure (Scott 1990:96).

This is because most protests and challenges - even quite violent ones - 'are made in the realistic expectation that the central features of the form of domination will remain intact'. Consequently, '[m]ost acts of power from below, even when they are protests - implicitly or explicitly - will largely observe the 'rules' even if their objective is to undermine them' (Scott:1990:93). Scott believes 'the historical evidence clearly shows that subordinate groups have been capable of revolutionary thought that repudiates existing forms of domination' (Scott 1990:101). However, because the occasions on which subordinate groups have been able to act openly and fully on that thought are rare, the conflict will usually take 'a dialogic form in which the language of the dialogue will invariably borrow heavily from the terms of the dominant ideology prevailing in the public transcript'. Consequently, we must 'consider the dominant discourse as a plastic idiom or dialect that is capable of carrying an enormous variety of meanings, including those that are subversive of their use as intended by the dominant' (Scott 1990:102-103, 138; see also Comaroff and Comaroff 1991:31).

Given Scott's analysis, subordinate groups are already engaged in forms of resistance and already have a language. 'The culture of silence' is a strategy and not the whole story. What is hidden is hidden for good reason, so any attempt to penetrate the disguise is dangerous. And when dignity and autonomy demand an irruption or an articulation, this must be done in ways determined by the dominated. There does not appear to be a silence to break or a language to create. An analysis in these terms suggests, in addition, that ordinary indigenous African 'readers' already have their own resources for appropriating the Bible.

I am not suggesting, however, that there is no place for organic intellectuals or socially engaged biblical scholars and their critical resources. ${ }^{9}$ To the contrary, much of my own work demonstrates the creative and critical possibilities of a sharing of resources between socially engaged biblical scholars and ordinary African 'readers' of the Bible (West 1995:174-192). One of my purposes in this article is to probe more carefully just what is their place in this process.

However, before we can have any place in the process - before we can enter into a meaningful and empowering alliance with ordinary African 'readers' - we must have acknowledged the resources those 'readers' already have. How can we 'drink from our own wells' (Maluleke 1996:3) when we denigrate them or deny their very existence and rely on imported, bottled water (or worse, Coca Cola)? Perhaps ordinary African 'readers' can help us

9. Patricia Hill Collins characterizes organic intellectuals as those who 'depend on common sense and represent the interests of their own group' in contrast to what she calls 'academicians' who 'trained to represent the interests of groups in power' (1990:18 note 5). 
recover readings of the Bible that our training blinds us to; perhaps, to return to an earlier example, ordinary African 'readers' do have resources which tame and subvert what may have been originally oppressive texts. ${ }^{10}$ Whatever their 'original' intention - and we must not forget that the notion of 'intention' is itself contested - there are host of strategies for reading texts against any alleged intention. Critical readers of the Bible have resources for doing this (for example, deconstruction), and, I am arguing, so do ordinary 'readers' - however, we are not as adept at describing their resources as we are at describing our own.

Wimbush describes the interpretative strategies of African slaves as 'characterized by a looseness, even playfulness' with respect to biblical texts (see above). This description does not seem to suggest the type of 'Word of God' hermeneutics Black and African theologians are charged with by Mosala, Mofokeng and, more recently, Maluleke. I do not want to dwell on or develop this line of argument, but I do want to insist that more careful analysis is required of exactly what particular Black and African theologians mean by their uses of the phrase 'Word of God'. ${ }^{11}$ My main point in this section and the next is to give substance to the claim of both Mosala and Mofokeng that ordinary Africans have their own resources for appropriating the Bible for their own purposes, including survival, resistance, liberation, and life. As already indicated, Wimbush's work goes some way to supporting such a claim. While Wimbush has attempted to elaborate and support this claim, our problem in South Africa is that we socially engaged biblical scholars (and theologians) have not concentrated on the reading resources and strategies of ordinary African 'readers' of the Bible, but have tended to analyse the methods and approaches of academically trained readers of the Bible. So when we discover that the interpretative tools and procedures of Black and African theologians resemble those of the missionaries and colonialists we should not be surprised - they have mastered their masters' training!

This does not mean, however, that academically trained biblical scholars and theologians are not able to turn their training against the agendas and ideologies of those who trained them. Mosala is an excellent example of a black biblical scholar who has used Western tools to dismantle dominant ideologies. Western modes of reading are not innocent, but neither are those who take them up as weapons of survival, resistance, liberation, and life! The Bible is not innocent, ${ }^{12}$ but neither are those untrained ordinary African interpreters who have appropriated it. Not only have they wrested ways of reading from their missionary and colonial masters and mistresses, but through their experiences they have also found and forged their own ways of 'reading' the Bible in order to fuel the working theologies they live by (see West 1996).

\section{Re-membering the Bible}

Before we re-envisage the role of the socially engaged biblical scholar I want to add a little more depth to the claim that ordinary African's have 'reading' resources of their own, by characterizing a cluster of interpretative strategies used by ordinary African 'readers'. My account is preliminary, but I hope it will contribute to the further work that needs to be done in this area. Throughout this article I have placed the term 'reading' in inverted commas. This acknowledges that I am using the term both literally, to include literate African readers, and

10. Deciding whether a text was 'originally' oppressive is not a certain science; see for example my discussion of Moslem's and Gunther Wittenberg's respective readings of the Cain and Abel story in West 1995:78.

11. Some analysis of the different ways in which Mosala and Allan Boesak use this phrase can be found in Frostin 1988:160-165 and West 1995:122-124.

12. Any claim that the Bible is a Western text is, of course, nonsense. Westem imperial forces may have brought this book to most of Africa, but its origins lie elsewhere (including Africa). See Tracy 1987 for a discussion of the fall from innocence of classic texts, including the Biblè. 
metaphorically, to include illiterate or partially literate African 'readers'. In most of the communities I work with ${ }^{13}$ the majority of Bible interpreters are either partially literate or illiterate; and yet they hear, remember, and retell the Bible. What they hear, remember, and retell is, I want to suggest, a remaking or a 're-membering' of the Bible.

Responding to the damage done by the Bible in Africa, the Zimbabwean theologian Canaan S. Banana called for the rewriting of the Bible (Banana 1993:17-32). Once again, as both Mosala and Mofokeng note, ordinary Africans are ahead of their trained compatriots. While they do not rewrite the Bible they do 're-member' it. Ordinary African interpreters of the Bible are not as transfixed and fixated by the text as their textually trained pastors and theologians; as Wimbush has indicated, their hermeneutics is characterized by 'a looseness' towards the biblical text. If they do speak of the Bible as 'Word of God', they do so in senses that are more metaphorical than literal; 'the Book' is more of a symbol than a text. ${ }^{14}$ The Bible they work with is always an already 'remembered' 'text'.

I use the term 're-membering', obviously, because of its derivation from the more familiar 're-membering'. In the South African context ordinary African interpreters work with a remembered as well as a read Bible. As Mosala reminds us, ordinary Africans, particularly in the African Independent Churches, 'have an oral knowlege of the Bible'. 'Most of their information about the Bible comes from socialisation in the churches themselves as they listen to prayers and sermons' (Mosala 1996:55). ${ }^{15}$ The 're-membering' of the Bible is, therefore, a communal process. Hearing, re-membering, and retelling are community acts (Nthamburi and Waruta 1997:52). This does not imply the absence of the Bible as text, for although the Bible as text is not central to the corporate practice of 're-membering', it does have a presence. Even those who are illiterate have considerable exposure to biblical texts being read. Reflecting on the Kenyan context Nahashon Ndungu notes 'even the illiterate members [of the Akurinu African Independent Church] take pains to master some verses which they readily quote when they give their testimonies'. These same members often carry copies of the Bible so that '[i]f need arises they can always request a literate member to read for them' (Ndungu 1997:62). The remembered Bible and the read Bible reside side by side. Both have a part in the process of 're-membering'; 're-membering' is not simply an oral activity.

Translation of the Bible into local languages has, of course, played a role in removing the remembered and written Bible from the control of the missionaries and colonialists. While I do not want to overstate this point, as I think Lamin Sanneh probably does, I agree with him that vernacular translation hands over the Bible, to some extent, to the ordinary African 'reader' (Sanneh 1989:3-5; see also Maluleke 1996:4 and Bediako 1994). Translation, then, has a part in 're-membering'.

I also use the term 're-membering' in Wimbush's way to refer to 'a looseness, even a playfulness' towards the text where interpretation is not controlled by the literal words of the texts, but by social experience; where texts are heard and retold more than read; where texts are engaged as stories that seize and free the imagination; where biblical texts are usually interpreted collectively; where biblical stories function sometimes as allegory, as parable, or as veiled social criticism in a situation where survival demands disguised forms of resisting

13. For a detailed account of what it means to work 'with' communities of ordinary readers see West 1996.

14. In much of Africa and among African in the diaspora the Bible is often used as 'a religio-magical instrument'; see Ndungu 1996:62-63, Ukpong 1994, and Yorke 1997:149-152.

15. Although Mosala's assessment here is based on African Independent Churches, it applies as well to the socalled main-line churches; see Draper 1996. 
discourse; where certain texts in the canon are read and others ignored (see above).

A less orthodox account, but one that resonates with Wimbush's, of what I mean by 'remembering' can be found in Osayande Obery Hendricks' concept of 'guerrilla exegesis' (Hendricks 1995). ${ }^{16}$ Guerilla exegesis, like 're-membering', takes whatever tools and resources are at hand, wherever they may come from, whether indigenous or imported, and uses them to sabotage and subvert hegemonic readings, to make new things out of old things, to find new truths in unexpected and familiar places, to redefine reality, to empower and inspire. 'Remembering', like guerilla exegesis, is eclectic and transgressive. 'Re-membering' is bricollage, is improvisation, is jazz. 'Re-membering' is '[u]sing whatever means you have in hand to free the meanings struggling to be freed, even if those means reside outside the bounds of methodological conventionality, outside the bounds of the hegemonic OK' (Hendricks 1995:79).

Finally, what I refer to as 're-membering' can also be characterized in a fourth way. Drawing on the work of Jacques Derrida and Laura Donaldson, Mary McClintock Fulkerson uses the phrase 'engraf(ph)ting' to speak of the reader's 'writing' of the text (Fulkerson 1994:152).

The Derridean play on the term graf(ph)t (combining graphion, Greek for stylus, and graft, a horticultural practice) evokes the materiality of writing by means of the horticultural practice that joins a cutting of a plant with another rooted one. A graft is other than the plant, even as it redirects the flow of sap, and depends for its life on the host; it creates a new plant. Similarly, a reading is an engraf(ph)ting on a text; it is not a mirror of a text, a repetition or imitation. A reading writes a text anew, stimulates its flow of meaning in new directions (Fulkerson 1994:152).

The usefulness of this trope 'is the inseparable - indeed, the constitutive - effect of social relations on the writing (production) of reader-practitioners, and the effect of readerpractitioners on the 'text' produced' (Fulkerson 1994:152).

A reading is a graf(ph)ted subject position, a textual position constructed out of the codes of the social formation. In the rewriting of the text, the redirected flow of that text is a splicing that directs our attention to the material relations that bring it into being. The graf(ph)t creates breaks, factures, and joints that mark off the needs, desires, pleasures, and fears of a subject position and elicit previously nonexistent possibilities in the text (Fulkerson 1994:152-153).

'Re-membering', then, is also 'engraf(ph)ting', particularly if we add to this latter term the South African English sense of 'graft' as 'hard work' ${ }^{17}$ and another sense of 'graft', which echoes Scott's account of the hidden transcript, as 'illicit spoils' (The Oxford English Dictionary). 'Re-membering' is a rewriting, a redirecting of meaning. 'Re-membering' writes a text anew from and for a particular social location. 'Re-membering' is hard work, is struggle. 'Re-membering' is forging meaning offstage, often at night.

Because the Bible as book - as text - is always present, even when it is not being read, the potential for the Bible as allegedly determinate text to overwrite what has been 're-membered' is always a possibility. ${ }^{18}$ Perhaps this is what Mosala means when he warns that 'oppressive

16. In what follows I have picked out those characteristics of guerilla exegesis that resonate with my understanding of 're-membering'.

17. This usage is also listed in The Oxford English Dictionary (1989) as slang.

18. See Fulkerson 1994:117-182 for a detailed poststructuralist account of the unstable text and readers as producers of meaning. 
texts cannot be totally tamed or subverted into liberating texts' (see above). His use of the qualifier 'totally' implies that he recognizes that texts can be partially subverted and tamed, but that the text (and its allegedly original intention) can always reassert itself. While text may be less malleable than memory, we must not underestimate the powerful presence of the 'remembered' 'text' as it permeates the life of the community. As with the initial encounter with the Bible, its use by the dominant (whether they read it with or against its alleged original intention) can be countered by the many moves that constitute 're-membering'. ${ }^{19}$ This, anyway, is my contention.

\section{Knowing our place}

Given my analysis, what is our place in the 'reading' process? Socially engaged biblical scholars and theologians have contributed and continue to contribute, in my view, to the interpretative practice of ordinary African 'readers'. Not only are they the bearers of additional potentially useful critical resources - to which we will turn shortly - but they usually inhabit the boundary regions which are the site of 'unremitting struggle' between the dominant and the dominated (Scott 1990:14). Boundaries are dangerous, precisely because of their ambiguity (Schreiter 1985:66), and so are those who cross boundaries. So, it is only the 'called' and 'converted' biblical scholar who may be of service to poor and marginalised communities those who have betrayed the hidden discourse of the dominant and who have chosen to be partially constituted by the hidden discourse of the dominated. ${ }^{20}$

Boundary crossers not only contribute spatially, helping to chart more clearly where the boundaries are; by offering resources that cross boundaries in and of time, socially engaged biblical scholars are able to open up potential lines of connection between particular past and present communities of faith (Schreiter 1985:18). In terms of Scott's analysis of domination and resistance this appears to be a particularly important contribution. The systematic and structured sets of questions that constitute the work of biblical scholars may provide other ways of 're-membering' and so appropriating the biblical text, and in so doing may enable what is incipient to become the social property of the group. As I have argued, local communities of poor and marginalized believers have their own hermeneutics of resistance and survival with which they 're-member' the Bible and construct their 'working' theologies. ${ }^{21}$ They may be naive and pre-critical, unsystematic and scattered, and they may draw incongrously on a range of symbols, rituals, readings and ideas, but they are theirs (Cochrane 90 and 181). In some cases these readings and theologies resonate with the readings and theologies of their churches; but often they do not, and so they have to be disguised and hidden. People then, for example, belong to the Anglican church by day and to a Zionist church by night - if they are fortunate enough to find a place to belong to by night where their incipient 'working' theology resonates with the 'official' theology of the church. Yet even here, in this marginal site, there may not be a place for the readings and theologies of some for example, of women.

When official or received readings are not meaningful, powerful, and true, then ordinary readers only have their own resources for 're-membering' the biblical tradition. For many this

19. There is also a deeper issue at stake here; ordinary 'readers' appear to accept poststructuralist notions of 'text' that only recently being recognized by biblical scholars (see Fulkerson 1994 and Semeia 72).

20. I am not sure that intellectuals from without the community ever have access to the hidden transcript; the zone between the hidden and public transcripts, what Scott calls 'infrapolitics' (xiii), may be all we ever have.

21. The 'working' theologies of ordinary Africans are often what Delores Williams calls 'survival' theologies (see Williams 1993:194-199). 
may mean a constant sense of discontinuity between their 're-membered' 'working' readings and theologies and the biblical tradition as they have encountered it. However, while working with socially engaged biblical scholars they have access to other resources - resources which offer other possibilities for continuity with other parts of the tradition. The interpretative resources of socially engaged biblical scholars offer forms of access to the boundaries of the biblical tradition that are not available to ordinary 'readers', and in so doing they provide opportunities for 'lines of connection' (Gottwald 1985:225) between the 'working' readings and theologies of poor and marginalized believers and previously inaccessible parts of the biblical tradition. Being able to find 'lines of connection' is potentially empowering because, as Rosemary Radford Ruether reminds us, to find glimmers of what is authentic and true for us in 'submerged and alternative traditions' is to 'assure oneself that one is not mad or duped' (Ruether 1983:18; see also West 1995:126-128).

Because Africans were confronted, converted, and catechized with particular parts and peculiar interpretations of Bible, it is these that have constituted the raw material of their 'remembering'. Organic intellectuals and other socially engaged biblical scholars and theologians open up additional parts of and perspectives on the Bible. Neglected and forgotten texts become available; those parts of the canon ignored by the missionaries and colonialists are now read. A plurality of perspectives open up and offer unexpected places of connection with the biblical tradition. In short, our additional tools provide increased capacities for critical interpretation and appropriation (see West 1996).

The readiness, in my experience, with which ordinary African 'readers' have embraced the otherness of our resources demonstrates their openness to critical resources. However, the way in which ordinary African 'readers' have taken up these critical resources demonstrates that they have not abandoned the array of interpretative resources they already possess. On receiving critical resources ordinary African 'readers' do not become purists who pursue particular interpretative perspectives. They do not; they do not because they read for purposes other than the production of academic papers - they 'read' for survival, liberation, and life (see Fulkerson 142-147). Our offerings as socially engaged biblical scholars may make a contribution to their struggle for survival, liberation, and life, but our contributions will be 'remembered' too - whether we approve or not.

We may not approve, but at the very least the socially engaged biblical scholar ought to be willing to be made use of (see Nolan 1996). Yet being of use should not be enough; we should want to be partially constituted by 'their' otherness. We too must be willing to read 'otherwise'. I want to make a number of points here. With respect to the reading process I have called 're-membering', I doubt that the trained reader can return to this form of reading, and I am not calling for a romantic return to pre-critical modes of reading. My cause is different; I want us socially engaged biblical scholars to see something of ourselves in the other. For example, Daniel Patte does just this when he argues that our critical readings are usually informed by our pre-critical readings (see Patte 1995). I concur with Patte: there are elements of 're-membering' in our critical readings. Systematic and structured though our interpretative selections and combinations may be, they are not innocent. Even our most rigorously critical readings show glimpses of our social interests and agendas (see Whitelam 1996). In other words, my first point is that there is something of the reading practices of 'the other' in ourselves - we too participate in forms of 're-membering'!22 Again, I must stress that I am not asking for a romanticizing or uncritical acceptance of these 'reading' practices; my argument

22. It can be argued that allowing any role to the reader in the construction of meaning requires some form of 'remembering' (see Fulkerson 1994:133-140. 
and appeal in this first point is that we must recognize and understand the resources ordinary African 'readers' use in their encounters with the Bible. We must recognize how 'they' read. In so doing we may learn something - about the Bible, text, our interpretative methods, and ourselves.

My second point concerns an understanding of why ordinary Africans read as they do. The process I have referred to as 're-membering' emerges, I have argued, from the lived realities of ordinary African 'readers' and their transactions with the Bible. I use this word 'transaction', with its economic and legal connotations, to signify that this process is not innocent. When the Bible was brought to Africa it was part of 'a package deal'. However, the missionaries and colonialists did not always have their own way. As Maluleke reminds us, 'While oppression and imperialism have been real and ruthless, Africans have at a deeper level negotiated and survived the scourge - by relativising it, resisting it, and modifying it with uncanny creativity' (Maluleke 1996:8). In the earlier parts of this article I have extended Maluleke's arguments to the Bible. While the Bible has been used for purposes of oppression and imperialism, both because of the ideologies of those who have used it and because of the ideologies intrinsic to it, ordinary Africans have at a deeper, often hidden, level negotiated and transacted with the Bible and partially appropriated the Bible - by relativising it, resisting it, and modifying it with uncanny creativity. This is what Wimbush means by 'a looseness' towards the text, what Hendricks means by 'guerilla exegesis', what Fulkerson means by 'engraf(ph)ting', and what I mean by 're-membering'. Although I have argued that we must be more careful, precise, and analytical in our use of terms like 'Word of God', whether we use the term ourselves or whether we use it to refer to the hermeneutical approaches of others, I agree with Maluleke when he says that while many African Christians 'may mouth the Bible-is-equal-to-the-Wordof-God formula, they are actually creatively pragmatic and selective in their use of the Bible so that the Bible may enhance rather than frustrate their life struggles' (Maluleke 1996:13).

My third and final point has to do with a more profound sense of 'knowing our place' in the reading process with ordinary African 'readers'. Owning up to who we are, to our social location, is becoming a constitutive element of our reading practice as biblical scholars (see Patte 1995 and Segovia and Tolbert 1995), but I am not sure that this is enough. As biblical studies begins to absorb (co-opt?) reader-orientated literary theory and the cultural studies movement 'it is becoming yet more clear that scholarly discourses themselves have histories and socio-economic locations' (Brett 1996:5). But does this acknowledgement, important as it is, require of us nothing more than saying who we are and then carrying on with business as usual $?^{23}$ I think not. Socially engaged biblical scholars ought to allow themselves to be partially constituted by 'their' life struggles - the life struggles of 'the other'. Our place is not only to offer and receive resources for transformative 'readings', our place is to be transformed by the 'reading' process. 'Reading with', as I have argued elsewhere (West 1996), reshapes our space and our place. 'Listening to' the narratives of 'others', especially those 'others' who have had to suffer our otherness imposed upon their 'readings' and resources is not enough. Tracy is right, the imperative to listen cannot be the final word. We must reject a pluralism that masks 'a genial confusion in which one tries' to enjoy the pleasures of difference without ever committing oneself to any particular vision of resistance and hope' (Tracy 1987:90). Our readings must, therefore, be located within a particular vision of resistance and hope which includes solidarity with the poor and marginalized. This too is our place.

Postmodern (and poststructuralist) impulses enable us to make this move - to relocate (see Waugh 1992:54-61, 114-164 and Fulkerson 1994). Drawing on these impulses Sharon Welch

23. See the essays in Semeia 72 for a range of explorations of the role of autobiography in biblical criticism. 
argues that we can only transcend 'the blinders of our own social location ... by recognizing the differences by which we ourselves are constituted and ... by actively seeking to be partially constituted by work with different groups' (Welch 1990:151). 'Reading with' others in contexts where we also work with them remakes us. Work with groups who have been differently constituted exposes us to some of the forces and factors that have constituted them and enables us to be partially constituted by them. Cultural feminism's and poststructuralist feminism's critique of the notion of universal experience and subjectivity insists that individual and communal selves are always in the process of being constructed and negotiated (see Kirby 1993 and Tolbert 1995:265-266), and that we must therefore consider more carefully and exactly, in the words of Kathleen Weiler, those forces 'in which individuals shape themselves and by which they are shaped' (Weiler 1991:449-74, 467; see also Spivak 1988:294). This understanding of subjectivity as 'the constant creation and negotiation of selves within structures of ideology and material constraints' not only offers us opportunities 'to articulate and claim a particular historical and social identity, to locate ourselves' and 'to build coalitions from a recognition of the partial knowledges of our own constructed identities' (Weiler 1991:469-470), but also offers us ways of becoming other than we are.

Work with poor and marginalized communities enables white middle-class male biblical scholars like me to be partially constituted by the experiences, needs, questions, and resources of other communities. This does not mean that my 'whiteness', 'middle-classness', and 'maleness' cease to be the major factors that constitute me, but they are no longer the whole story. I will need to be reminded again and again that I am indeed substantially shaped and indelibly inscribed by my whiteness, middle-classness, and maleness, but I now know that I need not remain content to be so. I can choose to be other. 


\section{BIBLIOGRAPHY}

Anderson, Janice Capel and Jeffrey L Staley (ed) 1995. Taking it Personally: Autobiographical Biblical Criticism, Semeia 72.

Banana, Canaan S 1993. 'The Case for a New Bible', in Isabel Mukonyora, James L Cox and Frans J Verstaelen (ed) 'Rewriting' the Bible: The Real Issues: Perspectives from within Biblical and Religious Studies in Zimbabwe. Gweru: Mambo Press, 17-32.

Barr, James 1980. Explorations in Theology 7: The Scope and Authority of the Bible. London: SCM.

Bediako, Kwame 1994. 'Epilogue', in Ype Schaaf On their Way Rejoicing: The History and Role of the Bible in Africa. Carlisle: Paternoster Press, 241-254.

Brett, Mark G 1996. 'Interpreting Ethnicity', in Mark G Brett (ed) Ethnicity and the Bible. Leiden: Brill, 3-22.

Cochrane, James R Circles of Dignity: Incipient Theologies and the Integrity of Faith in a Postcolonial Era, Unpublished Manuscript.

Collins, Patricia Hill 1990. Black Feminist Thought: Knowledge, Consciousness, and the Politics of Empowerment. London: Harper Collins.

Comaroff, Jean 1985. Body of Power, Spirit of Resistance: The Culture and History of a South African People. Chicago: University of Chicago Press.

Comaroff, Jean and John Comaroff 1991. Of Revelation and Revolution: Christianity, Colonialism and Consciousness in South Africa. Chicago: University of Chicago Press.

Croatto, Jóse Severino 1987. Biblical Hermeneutics: Toward aTheory of Reading as the Production of Meaning. Maryknoll NY: Orbis.

Draper, Jonathan A 1996. 'Confessional Western Text-Centred Biblical Interpretation and an Oral or Residual-Oral Context', Semeia 73, 59-77.

Frostin, Per 1988. Liberation Theology in Tanzania and South Africa: A First World Interpretation. Lund: Lund University Press.

Fulkerson, Mary McClintock 1994. Changing the Subject: Women's Discourses and Feminist Theology. Minneapolis: Fortress.

Getui, Mary N 1997. 'The Bible as a Tool for Ecumenism', in Hannah W Kinoti and John M Waliggo (ed) The Bible in African Christianity. Nairobi: Acton Publishers, 86-98.

Giroux, HA 1985. 'Introduction' in P Freire The Politics of Education. London: Macmillan, xi-xxv.

Gottwald, Norman K 1985. The Hebrew Bible: A Socio-Literary Introduction. Philadelphia: Fortress.

Gramsci, Antonio 1971. Selections from the Prison Notebooks. Quintin Hoare and Geoffrey Nowel Smith (ed). London: Lawrence and Wishart.

Hendricks, Osayande Obery 1995. 'Struggle' as a Scholarly Vocation: A Postmodern Approach to African-American Interpretation', Semeia 72, 73-90.

Kinoti, Hannah W and John M Waliggo (ed) 1997. The Bible in African Christianity: Essays in Biblical Theology. Nairobi: Acton Publishers.

Kirby, Kathleen M 1993. 'Thinking through the Boundary: The Politics of Location, Subjects, and Space', Boundary 2 20, 173-189.

Maluleke, Tinyiko Sam 1996. 'Black and African Theologies in the New World Order', Journal of Theology for Southern Africa 96, 3-19.

Mofokeng, Takatso 1998. 'Black Christians, the Bible and Liberation', Journal of Black 
Theology 2, 34-42.

Mosala, Itumeleng J 1986. 'Ethics of the Economic Principles: Church and Secular Investment', in Bhuti Tlhagale and Itumeleng J Mosala (ed) Hammering Swords into Ploughshares: Essays in Honour of Archbishop Mpilo Desmond Tutu. Johannesburg: Skotaville, 119-129.

Mosala, Itumeleng J 1987. Biblical Hermeneutics and Black Theology in South Africa. Cape Town University: PhD Thesis.

Mosala, Itumeleng J 1989. Biblical Hermeneutics and Black Theology in South Africa. Grand Rapids: Eerdmans.

Mosala, Itumeleng J 1996. 'Race, Classs, and Gender as Hermeneutical Factors in the African Independent Churhes' Appropriation of the Bible', Semeia 73, 43-57.

Ndungu, Nahashon 1997. 'The Bible in an African Independent Church', in Hannah W Kinoti and John M Waliggo (ed) The Bible in African Christianity. Nairobi: Acton Publishers, 58-67.

Nolan, Albert 1996. 'Work, the Bible, Workers, and Theologians: Element's of a Workers' Theology', Semeia 73, 213-220.

Nthamburi, Zablon and Douglas Waruta 1997. 'Biblical Hermeneutics in African Instituted Churches', in Hannah W Kinoti and John M Waliggo (ed) The Bible in African Christianity. Nairobi: Acton Publishers, 40-57.

Oxford English Dictionary 1989. Second Edition. Oxford: Clarendon.

Patte, Daniel 1995. Ethics of Biblical Interpretation: A Reevaluation. Louisville: Westminster John Knox.

Ruether, Rosemary Radford 1983. Sexism and God-talk: Towards a Feminist Theology. London: SCM.

Sanneh, Lamin 1989. Translating the Message: The Missionary Impact on Culture. Maryknoll NY: Orbis.

Schaaf, Ype 1994. On their Way Rejoicing: The History and Role of the Bible in Africa. Carlisle: Paternoster Press.

Schreiter, Robert J 1985. Constructing Local Theologies. Maryknoll: Orbis.

Scott, James C 1990. Domination and the Arts of Resistance: Hidden Transcipts. New Haven and London: Yale University Press.

Segovia, Fernando F and Mary Ann Tolbert (ed) 1995. Reading from this Place: Social Location and Biblical Interpretation in Global Perspective. Minneapolis: Fortress.

Spivak, Gayatri C 1988. 'Can the Subaltern Speak?', in Gary Nelson and L Grossberg (ed) Marxism and the Interpretation of Culture. London: Macmillan, 271-313.

Tolbert, Mary Ann 1995. 'Reading for Liberation', in Fernando F Segovia and Mary Ann Tolbert (ed) Reading from this Place: Social Location and Biblical Interpretation in the United States. Minneapolis: Fortress.

Tracy, David 1987. Plurality and Ambiguity: Hermeneutics, Religion, Hope. San Francisco: Harper Row.

Ukpong, Justin 1994. 'Port Harcourt Report of the Bible in Africa Project's Findings'. Port Harcourt: Unpublished Report.

Waugh, Patricia 1992. Practising Postmodernism: Reading Modernism. London: Edward Amold.

Weiler, Kathleen 1991. 'Freire and a Feminist Pedagogy of Difference', Harvard Educational Review 61, 449-474. 
Welch, Sharon D 1990. A Feminist Ethic of Risk. Minneapolis: Fortress.

West, Gerald O 1993. 'The interface between trained readers and ordinary readers in liberation hermeneutics - a case study: Mark 10:17-22', Neotestamentica 27, 165-80.

West, Gerald O 1994. 'Difference and Dialogue: Reading the Joseph Story with Poor and Marginalized Communities in South Africa', Biblical Interpretation 2, 152-170.

West; Gerald O 1995a. 'And the Dumb Do Speak: Articulating Incipient Readings of the Bible in Marginalised Communities', in John W Rogerson, Margaret Davies, and Daniel M Carroll, R (ed) The Bible in Ethics. Sheffield: Sheffield Academic Press, 174-192.

West, Gerald O 1995. Biblical Hermeneutics of Liberation: Modes of Reading the Bible in the South African Context. Second Edition. Maryknoll NY: Orbis.

West, Gerald O 1996. 'Reading the Bible Differently: Giving Shape to the the Discourses of the Dominated', Semeia 73, 21-41.

West, Gerald O 1997. 'Re-membering the Bible in South Africa: Reading Strategies in a Postcolonial Context', Jian Dao, 8:37-62.

West, Gerald O 1999. The Academy of the Poor: Towards a Dialogical Reading of the Bible. Sheffield: Sheffield Academic Press.

Williams, Dolores 1993. Sisters in the Wilderness: The Challenge of Womanist God-Talk. Maryknoll: Orbis.

Wimbush, Vincent L 1991. 'The Bible and African Americans: An Outline of an Interpretative History' in Cain Hope Felder (ed) Stony the Road We Trod: African American Biblical Interpretation. Minneapolis: Fortress, 81-97.

Wimbush, Vincent L 1993. 'Reading Texts Through Worlds, Worlds Through Texts', Semeia $62,129-140$.

Whitelam, Keith 1996. The Invention of Ancient Israel. New York: Routledge.

Yorke, Gosnell LOR 1997. 'The Bible in the Black Diaspora', in Hannah W Kinoti and John M Waliggo (ed) The Bible in African Christianity. Nairobi: Acton Publishers, 149-152. 